\title{
Revised N-Gram based Automatic Spelling Correction Tool to Improve Retrieval Effectiveness
}

\author{
Farag Ahmed, Ernesto William De Luca, and Andreas Nürnberger
}

\begin{abstract}
We present a language-independent spell-checker that is based on an enhancement of the n-gram model. The spell checker is proposing correction suggestions by selecting the most promising candidates from a ranked list of correction candidates that is derived based on n-gram statistics and lexical resources. Besides motivating and describing the developed techniques, we briefly discuss the use of the proposed approach in an application for keyword- and semantic-based search support. In addition, the proposed tool was compared with state-of-the-art spelling correction approaches. The evaluation showed that it outperforms the other methods.
\end{abstract}

Index terms-Spelling correction, n-gram, information retrieval effectiveness.

\section{INTRODUCTION}

$\mathrm{T}$ HE problem of devising algorithms and techniques to automatically correct words in texts has become a perennial research challenge. Work began as early as the 1960s on computer techniques for automatic spelling correction and automatic text recognition, and it has continued up to the present. There are good reasons for the continuing research efforts in this area in order to improve quality and performance and to broaden the spectrum of possible applications [1]. For example, even though system programs (language processors, operating systems, etc.) have become increasingly powerful and sophisticated, they do not assist the user (with very few exceptions) in correcting many of the obvious spelling errors in the source input. There are two types of word errors, the real-word error and the non-word error. Real-word errors are misspelled words that have a meaning and can be found in a dictionary. Non-word errors are words that have no meaning and are thus not included in a dictionary. We concentrate on the correction of the non-word error with the proposed algorithm. Damerau (1964) found that $80 \%$ of misspelled words that are non-word errors are the result of a single insertion, deletion, substitution or transposition of letters [2]. Therefore, it seems reasonable to base correction algorithms on measures that consider these simple operations. However, approaches based on pure n-

Manuscript received October 23, 2008. Manuscript accepted for publication August 22, 2009.

Farag Ahmed and Andreas Nürnberger are with Data and Knowledge Engineering Group, Institute for Knowledge and Language Engineering, Ottovon-Guericke University of Magdeburg, Germany.

Ernesto William De Luca is with Compentence Center Information Retrieval \& Machine Learning Distributed Artificial Intelligence Laboratory, Technical University of Berlin, Germany. gram statistics (which account for these operations implicitly) have also proven to provide good performance $[1,15]$.

In this paper, we propose an approach that is based on an enhancement of the n-gram model. Therefore, we first discuss briefly, related work on spelling correction in Section 2. Afterwards, we describe, in detail, in Section 3 our spell checking approach MultiSpell. In Section 4, we present an evaluation based on benchmark data sets in the English and Portuguese language and conclude with a brief discussion.

\section{APProAches OF SOME SPELl CHECKERS}

Algorithmic techniques for detecting and correcting spelling errors in text have a long and robust history in computer science [1]. Many approaches have been applied since people started to deal with this problem. Different techniques like edit distance [4], rule-based techniques [10], n-grams [20], probabilistic techniques [14], neural nets [15], similarity key techniques $[16,17]$ and noisy channel model $[18,19]$ have been proposed. All of these are based on the idea of calculating the similarity between the misspelled word and the words contained in a dictionary. In the following, we describe briefly one of the most popular approaches (Aspell) and one recently proposed approach for the Portuguese language (TST) [13] that we used for comparison.

GNU Aspell, usually called just Aspell, is a standard spellcheck software for the GNU software system. There are dictionaries for about 70 languages available. GNU Aspell is a Free and Open Source and can be downloaded under http://aspell.sourceforge.net/. In contrast to Ispell, which suggests words with small edit-distance, Aspell in addition compares sounds-like equivalents (computed for English words using the metaphone algorithm [21]) up to a given edit distance.

The Ternary Search Trees [13] approach (TST) is a dictionary data structure working with string-keys. It can find, remove and add these keys quickly and also easily search the tree for partial matches. Additionally, near-match functions can be implemented. These give the possibility to suggest alternatives for misspelled words.

For a more conclusive overview of spell-check approaches see $[1,15]$. 


\section{An ALGORIthm BASED ON N-GRAm StATISTICS: MULTISPELL}

The algorithm we propose, in the following, is a languageindependent spell-checker that is based on an enhancement of the n-gram model. It is able to detect the correction suggestions by assigning weights to a list of possible correction candidates, based on n-gram statistics and lexical resources, in order to detect the non-word errors and to derive correction candidates. In the following, we describe first of all the lexical re-source we used (MultiWordNet) and then in detail the proposed MultiSpell algorithm.

\section{A. Lexical Resources}

Lexical resources provide linguistic information about words of natural languages. This information can be represented in very diverse data structures, from simple lists to complex resources with many types of linguistic information and relations associated with the entries stored in the resource.

These resources are used for preparing, processing and managing linguistic information and knowledge needed for the computational processing of natural language [3]. An example of such large scale lexical resources is given by linguistic ontologies that cover many words of a language and have a hierarchical structure based on the relationship between concepts.

We propose to use these dictionaries, and especially MultiWordNet [6], the most important lexical resource available. It covers nouns, verbs, adjectives and adverbs. For our purpose, we use the words provided ( $>80000$ entries for the English language) from this resource to correct the misspelled word. Therefore, we extracted all words contained in it with all its linguistic relationships.

\section{B. Computing Similarity Scores Based on N-Grams}

The idea of using $n$-grams in language processing was discussed first by Shannon [8]. After this initial work, the idea of using n-grams has been applied to many problems such as word prediction, spelling correction, speech recognition, translated word correction and string searching. One main advantage of the $\mathrm{n}$-gram method is that it is language independent.

In a spelling correction task, an $n$-gram is a sequence of $n$ letters in a word or a string. The n-gram model can be used to compute the similarity between two strings, by counting the number of similar $\mathrm{n}$-grams they share. The more similar $\mathrm{n}$ grams between two strings exist the more similar they are. Based on this idea the similarity coefficient [9] can be derived. The similarity coefficient $\delta$ is defined by the following equation:

$$
\delta_{n}(a, b)=\frac{|\alpha \cap \beta|}{|\alpha \cup \beta|}
$$

where $\alpha$ and $\beta$ are the n-gram sets for two words $a$ and $b$ to be compared. $|\alpha \cap \beta|$ denotes the number of similar n-grams in $\alpha$ and $\beta$, and $|\alpha \cup \beta|$ denotes the number of unique ngrams in the union of $\alpha$ and $\beta$. Table I shows an example for the calculation of the similarity coefficient for the misspelled word "secceeded" and the correct word "succeeded" using an n-gram with $\mathrm{n}=2$ (bigram).

TABLE I

CALCULATING THE BIGRAMS SIMILARITY COEFFICIENT BETWEEN TWO STRINGS.

\begin{tabular}{ccc}
\hline bi-grams union & succeeded & secceeded \\
\hline$s u$ & 1 & - \\
$u c$ & 1 & - \\
$c c$ & 1 & 1 \\
$c e$ & 1 & 1 \\
$e e$ & 1 & 1 \\
$e d$ & 1 & 1 \\
$d e$ & 1 & 1 \\
$e d$ & 1 & 1 \\
$s e$ & - & 1 \\
$e c$ & - & 1 \\
Similarity coefficient & & $6 / 10=0.6$ \\
\hline
\end{tabular}

\section{Revised N-Gram Based Approach}

Yannakoudakis and Fawthrop [10] found that in most cases the first letter in the misspelled word is almost always correct and also the misspelled and real word will be either the same length or the length differs just by one. For some examples, we like to refer the reader to the list of commonly misspelled words in English published in [12]. Furthermore, the pure ngram based approach to compute the similarity coefficient as described above, does not consider the order of the n-grams [22]. This might, however, be important since typing or misspelling errors usually affect only a specific part of the word. Therefore, we revised the computation of a similarity between words to take these two aspects into account.

In the following, we describe our algorithm for $n=2$ (bigrams) for simplicity. However, the approach can be applied for trigrams and n-grams with $n>3$ as well. We define bigrams of words by their respective position in the word $w_{i, i+(n-1)}$ where $i$ defines the position of the first letter and $i+(n-1)$ the position of the last letter of the considered $\mathrm{n}$-gram. Thus, the last possible position of an $\mathrm{n}$-gram in a word is defined by $j=|w|-n+1$, where $|w|$ defines the length of the word.

In order to consider the findings of Yannakoudakis and Fawthrop as mentioned above, we replace the first and the last n-gram by the first and the last letter of the respective words. Thus, when computing the similarity score these elements are compared directly, independent of the remaining n-grams between them.

In order to deal with the second aspect mentioned above, we define a window of $n$-grams of the correction candidate words that should be compared, i.e. while in Eq. (1) all ngrams are compared with each other, we only compare ngrams that are in close proximity to the position of the n-gram in the word to be corrected when computing the similarity score. An example is given in Fig. 1, where $w^{\prime}$ defines the misspelled word and $w$ a correction candidate. Here, the $n-$ gram $w_{4,5}^{\prime}$ of $w^{\prime}$ will only be compared to the n-grams $w_{3,4}$, 
$w_{4,5}$ and $w_{5,6}$ of the correction candidate $w$, i.e. even if the $n-$ gram $w_{4,5}^{\prime}$ is similar to $w_{2,3}$ this would not count towards the similarity score of the words $w^{\prime}$ and $w$.

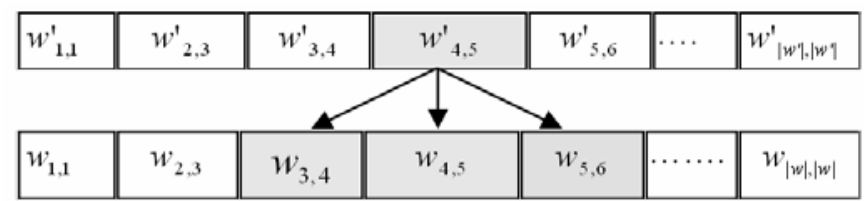

Fig. 1. Bigram comparison for misspelled word w' and a correction candidate w using a comparison window of size 3 . Notice that the first and last n-gram represent the first and the last letters only and are therefore always of size one.

Overall, the computation of the similarity score $S$ for a given n-gram size $n$ and a given odd-numbered window size $m$ can be defined as follows, assuming that $u$ is the longer word (if $v$ is longer than $u$ and $v$ can simply be exchanged):

$$
\begin{aligned}
& S_{n, m}(u, v)= \\
& g\left(u_{1,1}, v_{1,1}\right)+g\left(u_{|u|,|u|}, v_{|v|, v \mid}\right)+\sum_{i=2}^{|u|-n+1} \sum_{j=-\frac{m-1}{2}}^{\frac{m-1}{2}} g\left(u_{i, i+(n-1)}, v_{i+j, i+j+(n-1)}\right) \\
& \hline
\end{aligned}
$$$$
N
$$

$$
\begin{gathered}
\text { where } g(a, b)=\left\{\begin{array}{ll}
1 & \text { if } a=b \\
0 & \text { otherwise }
\end{array}\right. \text { and } \\
u_{i, j}= \begin{cases}\operatorname{substring}(u, i, j) & \text { if } i<=j \\
" \prime \prime & \text { otherwise. }\end{cases}
\end{gathered}
$$

Here, $g\left(u_{1,1}, v_{1,1}\right)$ compares the first and $g\left(u_{|u|,|u|}, v_{|v|,|v|}\right)$ the last characters of the words $u$ and $v$ and the nested sum counts the number of n-grams in $v$ that are similar to n-grams in a window of size $m$ around the same position in word $v$. $N$ is computed similarly as in Eq. (1). In Fig. 2 the specific cases that have to be considered when computing the similarity score $S$ are summarized.

\section{The MultiSpell Algorithm}

The first stage of the MultiSpell algorithm is to compare the keywords given from the user with the correct words contained in the dictionary. First of all, we check based on the used dictionary (here, based on the words extracted from MultiWordNet) if the word is misspelled. If this is the case, the algorithm builds n-grams for the misspelled word. Then we select correction candidates from the dictionary. In order to keep the number of correction candidates as small as possible, we select only words as candidates that are two charters shorter or longer than the misspelled word. This is motivated by the work of Turba [11], who has shown that most misspelled words differ in length only by one character from the correct word.
For the selected words the n-grams are computed and the similarity score is computed according to Eq. (2). The correction candidates can then be simply sorted by the obtained similarity score and the word with the highest score is proposed as the best correction candidate.

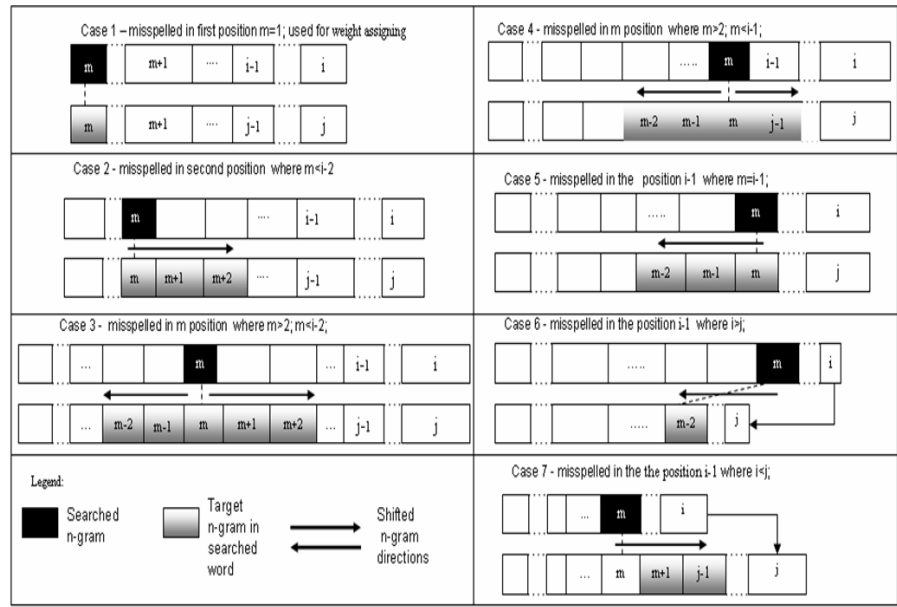

Fig. 2. Comparing n-grams based on the MultiSpell algorithm.

\section{E. Spelling Correction for Keyword- and Semantic-based Search Support}

MultiSpell has been also integrated as a pre-processing approach in the Sense Folder Framework [25]. It can be applied to queries and documents, in order to support users during keyword-based and semantic-based search. The first is an important task for retrieving the relevant documents related to the query identifying the misspelled words and correct them for a correct interpretation [23] (see also Fig. 3). The second is specifically trying to improve the semantic search process [24]; therefore several problems have to be addressed, before the semantic classification of documents is started. When users mistype the query in writing, the system has to be able to give correction alternatives to continue the semantic-based search.

The semantic-based search differs from the "normal" search, because users are "redirected" to semantic concepts that could describe their query. This semantic support is provided in the user interface. On the left side of the user interface (see Fig. 4) suggestions are generated by MultiSpell and presented to the user for starting the semantic-based search.

In this case, the use of Multispell is mostly helpful, not only because it performs an efficient correction (as shown in Fig. 3), but also because it can "redirect" the user to a semantic search (see Fig. 4). Thus, if the user types a word that is not contained in the lexical resource used, the system can suggest other "similar" words according to the words found in the resource. Then, a semantic classification is started using the words selected by the user. 


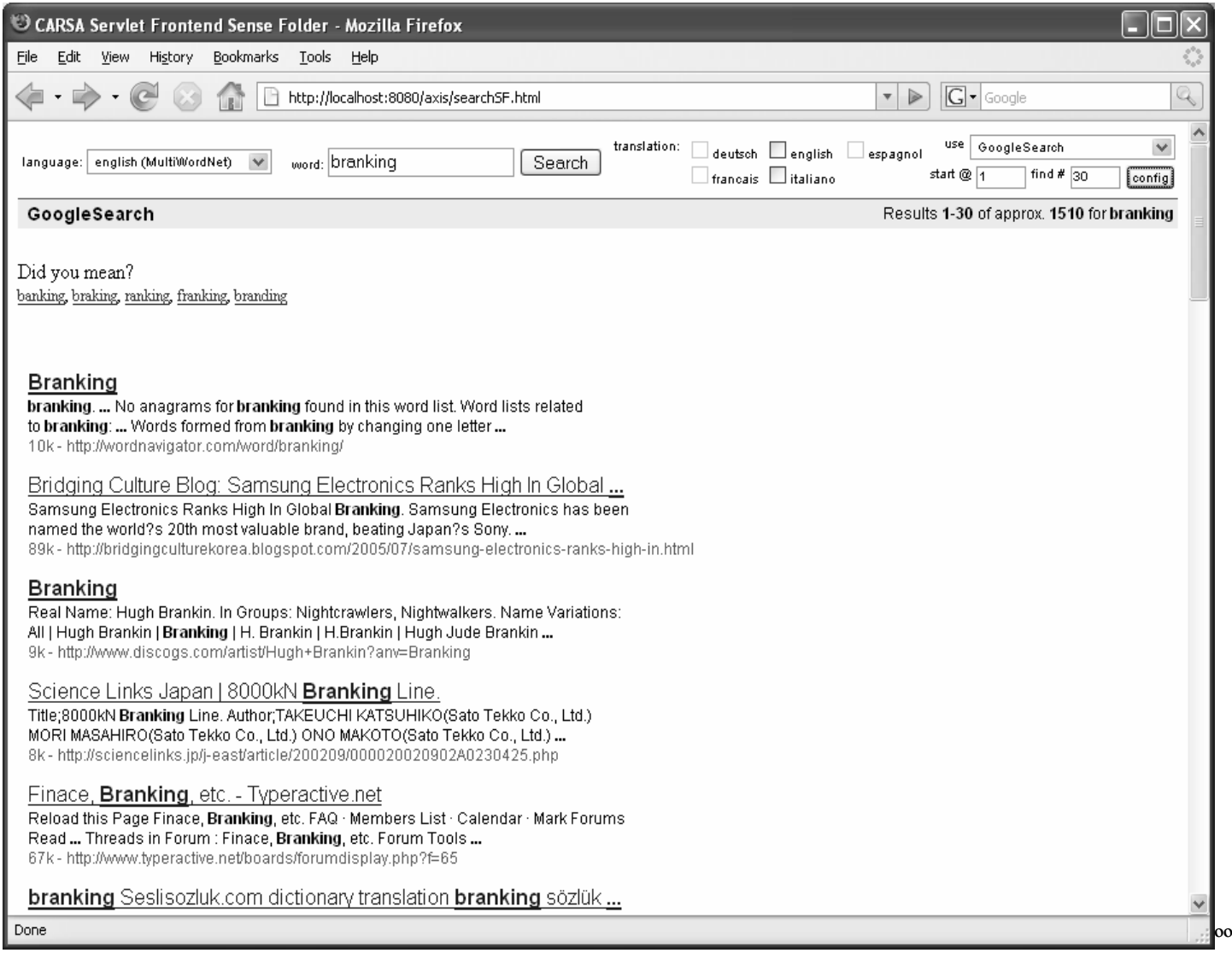

Fig. 3. Corrections for a misspelled word (MultiSpell) in the Sense Folder Framework .

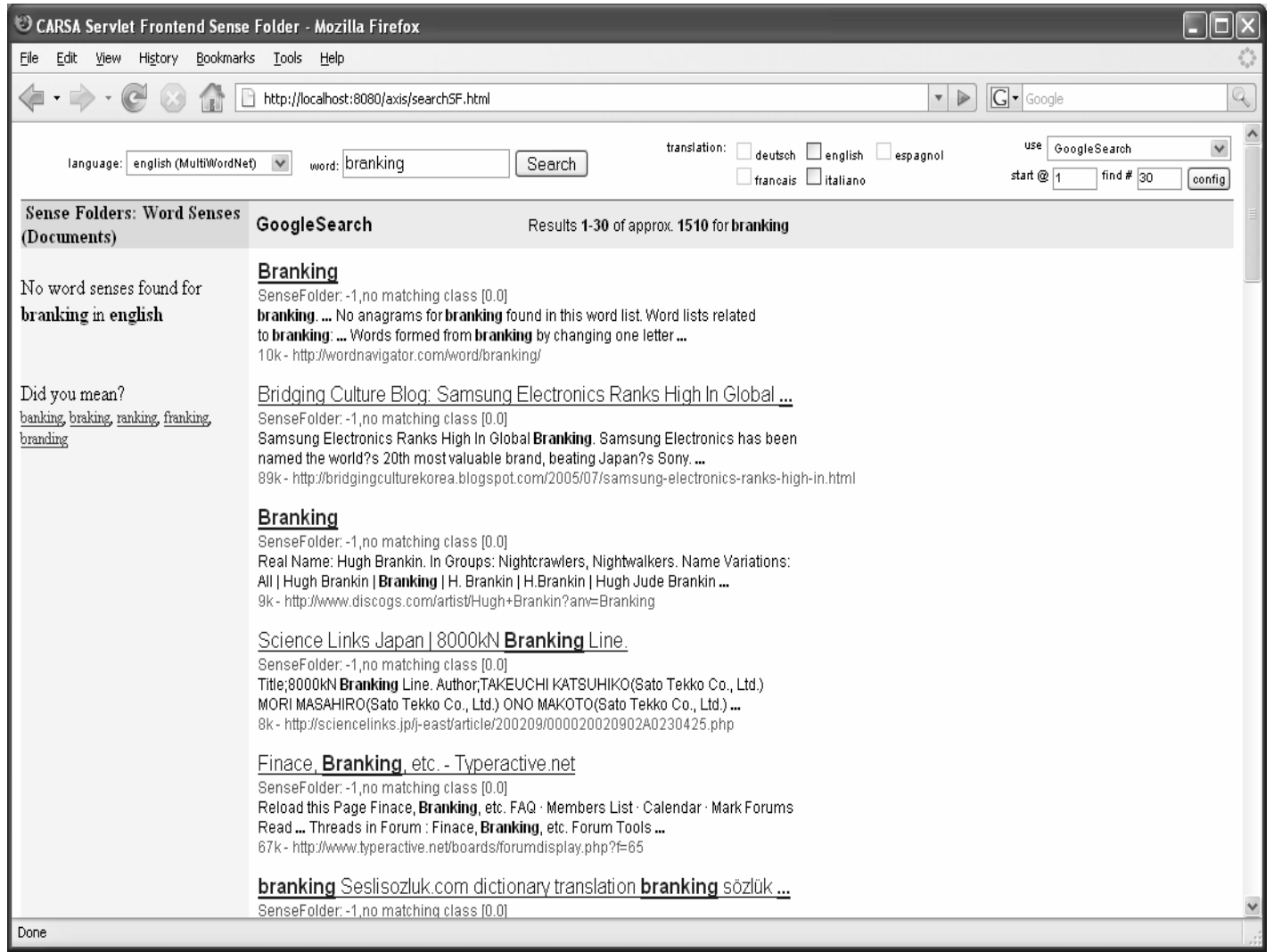

Fig. 4. Using MultiSpell in the Sense Folder Framework for Semantic Search Support. 


\section{COMPARISON AND EVALUATION OF RESULTS}

In the following, we show results of some experiments done for the English and Portuguese language. The first evaluation was done on the whole English commonly misspelled word list provided in [12]. Afterwards, we compared the results of our spell checker MultiSpell with the results of the TST approach (in one experiment, for the Portuguese language) and of the Aspell approach (in two experiments, for the Portuguese and the English language), showing that the proposed approach always achieved the best results.

For the first evaluation, we used the whole list of commonly misspelled words in English consisting of 3975 words as published in [12]. This list of common spelling mistakes is represented by a table consisting of two columns. The first one shows the misspelled word, the second the correct spelling. For the evaluations, we only considered the correction words that were ranked as best correction word, i.e., even if the second word would have been the correct candidate, this was counted as a wrong correction. We first used all misspelled words of the list, using the bigram case and just the first candidate correction. MultiSpell corrected 3334 misspelled words (84\%) and failed for 641 misspelled words (16\%) although it provided similar corrections in many cases. For example the word advice was suggested instead of advised for the misspelled word advised. Another example is the provided correction algebraically instead of algebraic for the misspelled word algebraical (see Table $\mathrm{V}$ in the Appendix). These suggestions were classified as wrong in our approach, even though they belong to the same word sense. Second, we used trigrams. This showed lower performance and efficiency. MultiSpell corrected 2900 words (73\%) and failed for 1075 $(27 \%)$ as shown in Table II.

\section{A. Evaluation of English Spelling Correction}

For the second evaluation, we randomly selected a set of only 120 misspelled words obtained from Wikipedia [12] and not the whole list. All error types and starting letters of the words were taken into account. We compared MultiSpell with Aspell, MicrosoftWord, and Google. Since Aspell provides a list of candidate corrections we took just the first candidate from the list assuming that the first candidate is the most likely one proposed by the algorithm. MicrosoftWord and Google provided only one correction candidate. Table III and Table V (in the Appendix) show that MultiSpell finds the correct spelling for 109 words (90\%). In comparison, Google can correct 106 (88\%) words, while Aspell and MicrosoftWord 105 words $(87.5 \%)$. MultiSpell detected 6 of 16 of the multiple correction words (which have more than one possible correction), but it doesn't fail to provide at least one correct suggestion. Aspell detected just two of the multiple corrections and it failed just one time to provide a suggestion for one of the multiple corrections.
TABLE II

COMPARISON BETWEEN BIGRAM AND TRIGRAM IN WHOLE ENGLISH DATA SET (3975 WORDS).

\begin{tabular}{lcc}
\hline & \multicolumn{1}{l}{ bigram } & \multicolumn{1}{c}{ trigram } \\
\hline correct & $3334(84 \%)$ & $2900(73 \%)$ \\
wrong & $641(16 \%)$ & $1075(27 \%)$ \\
\hline
\end{tabular}

TABLE III

COMPARISON OF MULTiSPEll, ASPELl, Microsoft WORD AND GOOGLE FOR ENGLISH.

\begin{tabular}{ccccc}
\hline & MultiSpell & Aspell & Microsoft Word & Google \\
\hline correct & $109(90 \%)$ & $105(87.5 \%)$ & $105(87.5 \%)$ & $106(88 \%)$ \\
wrong & $11(10 \%)$ & $15(12.5 \%)$ & $15(12.5 \%)$ & $14(12 \%)$ \\
\hline
\end{tabular}

TABLE IV

COMPARISON OF MULTISPELL, ASPELL AND TST FOR THE PORTUGUESE LANGUAGE.

\begin{tabular}{llll}
\hline & MultiSpell & TST & Aspell \\
\hline correct & $97(80 \%)$ & $78(65 \%)$ & $65(54 \%)$ \\
wrong & $23(20 \%)$ & $42(35 \%)$ & $55(46 \%)$ \\
\hline
\end{tabular}

\section{B. Evaluation of Portuguese Spelling Correction}

The last evaluation was done for the Portuguese language. Bruno and Mário [13] implemented an algorithm using Ternary Search Trees (TST). The authors show experiments in correcting a list of some Portuguese words and comparing their results with Aspell. Here we compared MultiSpell on the whole list (120 Portuguese words) available from their experiments explained in [13], applying our algorithm and comparing it with the Aspell and TST algorithm. Given that MultiWordNet does not provide any Portuguese word senses, we used the dictionary made available from [13] comparing the approaches. Our algorithm succeeded to correct 97 misspelled words $(80 \%)$, TST succeeded to correct 78 misspelled words $(65 \%)$ and Aspell succeeded to correct 65 misspelled words (54\%) as shown in Table IV and Table VI (in the Appendix).

\section{CONCLUSIONS}

In this paper we proposed a language-independent spellchecker that is based on an enhancement of a pure n-gram based model. Furthermore, we presented evaluations on English and Portuguese benchmark data sets of misspelled words. The obtained results outperformed other state-of-theart methods. In future work, we plan to further optimize the algorithm and data structure used to compute the similarity scores. Furthermore, the algorithm should be tested on data sets for other languages. 


\section{APPENDIX: EvaluAtion TABLES FOR ENGLish AND PORTUGUESE}

Table V contains results of word corrections in English, while Table VI contains results of word corrections in Portuguese.

TABLE V

RESULTS OF WORD CORRECTIONS IN ENGLISH.

\begin{tabular}{|c|c|c|c|c|c|}
\hline Misspelling & Correct Spelling & Aspell & Microsoft word & Google & MultiSpell \\
\hline Abberration & aberration & aberration & aberration & aberration & aberration \\
\hline accomodation & accommodation & accommodation & accommodation & accommodation & accommodation \\
\hline acheive & achieve & Achieve & achieve & achieve & achieve \\
\hline abortificant & abortifacient & aficionados & - & abortifacient & abortifacient \\
\hline absorbsion & absorption & absorbs ion & absorpsion & absorption & absorption \\
\hline ackward & (awkward, backward) & awkward & (awkward, backward) & awkward & (awkward, backward) \\
\hline additinally & additionally & additionally & additionally & additionally & additionally \\
\hline adminstration & administration & administration & administration & administration & administration \\
\hline admissability & admissibility & admissibility & admissibility & admissibility & admissibility \\
\hline advertisments & advertisements & advertisements & advertisements & advertisements & advertisements \\
\hline adviced & advised & advised & advised & $\underline{\text { advice }}$ & $\underline{\text { advice }}$ \\
\hline afficionados & aficionados & aficionados & aficionados & aficionados & aficionados \\
\hline affort & (effort ,afford) & effort & afford & afford & afford \\
\hline agains & against & agings & agings & against & against \\
\hline aggreement & agreement & agreement & agreement & agreement & agreement \\
\hline agressively & aggressively & aggressively & aggressively & aggressively & aggressively \\
\hline agriculturalist & agriculturist & - & - & - & agriculturist \\
\hline alcoholical & alcoholic & alcoholically & $\underline{\text { alcoholically }}$ & alcoholic & alcoholic \\
\hline algebraical & algebraic & algebraic & algebraically & algebraic & algebraically \\
\hline algoritms & algorithms & algorithms & $\overline{\text { algorithms }}$ & algorithms & $\overline{\text { algorithms }}$ \\
\hline alterior & (ulterior, anterior) & ulterior & (anterior, ulterior) & ulterior & (anterior, ulterior) \\
\hline anihilation & annihilation & annihilation & annihilation & annihilation & annihilation \\
\hline anthromorphization & anthropomorphization & anthropomorphizing & - & - & anthropomorphization \\
\hline bankrupcy & bankruptcy & bankruptcy & bankruptcy & bankruptcy & bankruptcy \\
\hline baout & (about,bout) & bout & (about,bout) & about & bout \\
\hline basicly & basically & basically & basically & basically & basically \\
\hline breakthough & breakthrough & break though & breakthrough & breakthrough & breakthrough \\
\hline carachter & character & crocheter & character & character & character \\
\hline cannotation & connotation & $\overline{\text { connotation }}$ & (connotation & connotation & (connotation \\
\hline & & & ,annotation) & & ,annotation) \\
\hline carismatic & charismatic & charismatic & charismatic & charismatic & charismatic \\
\hline carmel & caramel & Carmel & - & - & caramel \\
\hline cervial & (cervical, servile) & cervical & cervical & cervical & cervical \\
\hline clasical & classical & classical & classical & classical & classical \\
\hline cleareance & clearance & clearance & clearance & clearance & clearance \\
\hline comissioning & commissioning & commissioning & commissioning & commissioning & commissioning \\
\hline commemerative & commemorative & commemorative & commemorative & commemorative & commemorative \\
\hline compatabilities & compatibilities & compatibilities & compatibilities & compatibilities & compatabilities \\
\hline committment & commitment & commitment & commitment & commitment & commitment \\
\hline debateable & debatable & debatable & debatable & debatable & debatable \\
\hline determinining & determining & determinining & determinining & determinining & determining \\
\hline childbird & childbirth & child bird & child bird & _childbirth & childbirth \\
\hline definately & definitely & $\overline{\text { definitely }}$ & definitely & definitely & definitely \\
\hline decribe & describe & describe & describe & describe & describe \\
\hline elphant & elephant & elephant & elephant & elephant & elephant \\
\hline emmediately & immediately & immediately & immediately & immediately & immediately \\
\hline emphysyma & emphysema & emphysema & emphysema & emphysema & emphysema \\
\hline erally & (orally, really) & orally & really & really & orally \\
\hline eyasr & (years, eyas ) & eyesore & years & years & eyas \\
\hline facist & fascist & $\overline{\text { fascist }}$ & fascist & fascist & fascist \\
\hline fluoroscent & fluorescent & fluorescent & fluorescent & fluorescent & fluorescent \\
\hline geneology & genealogy & genealogy & genealogy & genealogy & genealogy \\
\hline gernade & grenade & grenade & grenade & grenade & grenade \\
\hline girates & gyrates & grates & gyrates & pirates & gyrates \\
\hline
\end{tabular}




\begin{tabular}{|c|c|c|c|c|c|}
\hline Misspelling & Correct Spelling & Aspell & Microsoft word & Google & MultiSpell \\
\hline gouvener & governor & governor & $\underline{\text { souvenir }}$ & gouverneur & convener \\
\hline gurantees & guarantee & guarantee & $\overline{\text { guarantee }}$ & guarantee & guarantee \\
\hline guerrila & (guerilla, guerrilla) & guerrilla & guerrilla & guerrilla & (guerilla, guerrilla) \\
\hline guerrilas & (guerillas, guerrillas) & guerrillas & guerrillas & guerrillas & (guerillas, guerrillas) \\
\hline Guiseppe & Giuseppe & Giuseppe & Giuseppe & Giuseppe & Giuseppe \\
\hline habaeus & (habeas, sabaeus) & habeas & habitués & habeas & sabaeus \\
\hline $\begin{array}{l}\text { hierarcical } \\
\text { heros }\end{array}$ & $\begin{array}{c}\text { hierarchical } \\
\text { heroes }\end{array}$ & $\begin{array}{l}\text { hierarchical } \\
\text { heroes }\end{array}$ & $\begin{array}{l}\text { hierarchical } \\
\text { heroes }\end{array}$ & $\begin{array}{l}\text { hierarchical } \\
\text { heroes }\end{array}$ & $\begin{array}{c}\text { hierarchical } \\
\text { herbs }\end{array}$ \\
\hline hypocracy & hypocrisy & hypocrisy & hypocrisy & hypocrisy & hypocrisy \\
\hline independance & Independence & Independence & - & Independence & Independence \\
\hline $\begin{array}{c}\text { intergration } \\
\text { intrest }\end{array}$ & $\begin{array}{c}\text { integration } \\
\text { interest }\end{array}$ & $\begin{array}{c}\text { integration } \\
\text { interest }\end{array}$ & $\begin{array}{l}\text { integration } \\
\text { interest }\end{array}$ & $\begin{array}{c}\text { integration } \\
\text { interest }\end{array}$ & $\begin{array}{c}\text { integration } \\
\text { interest }\end{array}$ \\
\hline Johanine & Johannine & Johannes & Johannes & Johannes & Johannine \\
\hline judisuary & judiciary & judiciary & judiciary & - & judiciary \\
\hline kindergarden & kindergarten & kindergarten & kindergarten & kindergarten & kindergarten \\
\hline knowlegeable & knowledgeable & knowledgeable & knowledgeable & knowledgeable & knowledgeable \\
\hline labatory & (lavatory, laboratory) & (lavatory, laboratory) & (lavatory, laboratory) & laboratory & (lavatory, laboratory) \\
\hline lonelyness & loneliness & loneliness & loneliness & loneliness & loneliness \\
\hline legitamate & legitimate & legitimate & legitimate & legitimate & legitimate \\
\hline libguistics & linguistics & linguistics & linguistics & linguistics & linguistics \\
\hline lisence & (license, licence) & licence & silence & licence & licence \\
\hline mathmatician & mathematician & mathematician & mathematician & mathematician & mathematician \\
\hline ministery & ministry & ministry & ministry & ministry & ministry \\
\hline mysogynist & misogynist & misogynist & misogynist & misogynist & misogynist \\
\hline naturaly & naturally & naturally & naturally & naturally & naturally \\
\hline ocuntries & countries & countries & countries & countries & countries \\
\hline paraphenalia & paraphernalia & paraphernalia & paraphernalia & paraphernalia & paraphernalia \\
\hline Palistian & Palestinian & Alsatain & politian & Palestinian & Palestinian \\
\hline pamflet & pamphlet & pamphlet & pamphlet & pamphlet & pamphlet \\
\hline psyhic & psychic & psychic & psychic & psychic & psychic \\
\hline Peloponnes & Peloponnesus & Peloponnese & Peloponnese & Peloponnese & Peloponnesus \\
\hline personell & personnel & personnel & personnel & personnel & personnel \\
\hline posseses & possesses & possesses & possesses & possesses & possess \\
\hline prairy & prairie & priory & prairie & prairie & airy \\
\hline qutie & (quite, quiet) & quite & quite & cutie & $\overrightarrow{\text { queue }}$ \\
\hline radify & (ratify,ramify) & ratify & ratify & $\overline{\text { ratify }}$ & $\overline{\text { ramify }}$ \\
\hline reccommended & recommended & recommended & recommended & recommended & recommended \\
\hline reciever & receiver & receiver & receiver & receiver & reliever \\
\hline reconaissance & reconnaissance & reconnaissance & reconnaissance & reconnaissance & reconnaissance \\
\hline restauration & restoration & restoration & restoration & restoration & instauration \\
\hline rigeur & (rigueur, rigour, rigor) & rigger & rigueur & - & (rigueur, rigour) \\
\hline Saterday & Saturday & Saturday & Saturday & Saturday & Saturday \\
\hline scandanavia & Scandinavia & Scandinavia & Scandinavia & Scandinavia & Scandinavia \\
\hline scaleable & scalable & scalable & - & scalable & scalable \\
\hline secceeded & (seceded, succeeded) & succeeded & succeeded & seceded & succeeded \\
\hline sepulchure & (sepulchre, sepulcher) & sepulcher & sepulchered & sepulcher & sepulchre \\
\hline themselfs & themselves & themselves & themselves & themselves & themselves \\
\hline throught & $\begin{array}{c}\text { (thought, through, } \\
\text { throughout) }\end{array}$ & (thought, through) & (thought ,through) & throat & $\begin{array}{l}\text { (thought, through, } \\
\text { throughout) }\end{array}$ \\
\hline troups & (troupes, troops) & (troupes, troops) & troupes & troops & troops \\
\hline simultanous & smultaneous & simultaneous & simultaneous & simultaneous & simultaneous \\
\hline sincerley & sincerely & sincerely & sincerely & sincerely & sincerely \\
\hline sophicated & sophisticated & suffocated & supplicated & - & sophisticate \\
\hline surrended & $\begin{array}{l}\text { (surrounded, } \\
\text { surrendered) }\end{array}$ & surrounded & surrender & surrender & surrounded \\
\hline unforetunately & unfortunately & unfortunately & unfortunately & - & unfortunately \\
\hline unnecesarily & unnecessarily & unnecessarily & unnecessarily & - & unnecessarily \\
\hline usally & usually & usually & usually & usually & usually \\
\hline useing & using & using & using & using & seeing \\
\hline vaccum & vacuum & vacuum & vacuum & vacuum & vacuum \\
\hline
\end{tabular}




\begin{tabular}{|c|c|c|c|c|c|}
\hline Misspelling & Correct Spelling & Aspell & Microsoft word & Google & MultiSpell \\
\hline vegitables & vegetables & vegetables & vegetables & vegetables & vegetables \\
\hline vetween & between & between & between & between & between \\
\hline volcanoe & volcano & volcano & volcano & volcano & volcano \\
\hline weaponary & weaponry & weaponry & weaponry & weaponry & weaponry \\
\hline worstened & worsened & worsened & worsened & - & worsened \\
\hline wupport & support & support & support & support & support \\
\hline yeasr & years & years & years & years & yeast \\
\hline Yementite & (Yemenite, Yemeni) & Yemenite & Yemenite & Yemenite & Yemenite \\
\hline yuonger & younger & Younger & younger & younger & sponger \\
\hline
\end{tabular}

TABLE VI

RESULTS OF WORD CORRECTIONS IN PORTUGUESE.

\begin{tabular}{|c|c|c|c|c|}
\hline Correct Form & Spelling Error & TST & Aspell & MultiSpell \\
\hline acerca & àcerca & acerca & acerca & acerca \\
\hline açoriano & açoreano & açoriano & coreano & açoriano \\
\hline alcoolémia & alcoolemia & alcoolÚmia & - & alcoolémia \\
\hline ameixial & ameixeal & ameixial & ameixial & ameixial \\
\hline antárctico & antártico & catártico & antárctico & antárctico \\
\hline antepor & antepôr & - & antepor & antepor \\
\hline árctico & artico & artigo & aórtico & aórtico \\
\hline artífice & artífece & artífice & $\overline{\text { artífice }}$ & $\overline{\text { artífice }}$ \\
\hline bainha & baínha & bainha & bainha & bainha \\
\hline bebé & bébé & bebé & bebe & bebé \\
\hline bege & beje & bege & $\overline{\text { beije }}$ & bejense \\
\hline bêncão & bencão & bencao & - & bêncão \\
\hline benefcência & benefciência & beneficência & beneficência & beneficência \\
\hline biopsia & biópsia & biópsiu & - & biopsia \\
\hline burburinho & borborinho & burburinho & burburinho & burburinho \\
\hline caiem & caem & - & - & cabem \\
\hline calvície & calvíce & calvície & calvície & $\overline{\text { calvície }}$ \\
\hline camoniano & camoneano & camoniano & camoniano & camoniano \\
\hline campeão & campião & campeão & campeão & campeão \\
\hline chiita & xiita & chiita & xiitas & xiitas \\
\hline comboio & combóio & comboio & comboio & comboio \\
\hline compor & compôr & - & compor & compor \\
\hline comummente & comumente & comovente & comummente & comummente \\
\hline constituia & constituía & - & - & constituia \\
\hline constituiu & constituíu & constituiu & constituiu & constituiu \\
\hline cor & côr & - & cor & cor \\
\hline crânio & crâneo & crânio & cárneo & crânio \\
\hline definição & defenição & definição & definição & definição \\
\hline definido & defenido & definido & - & defendido \\
\hline definir & defenir & definir & definir & definir \\
\hline desequilíbrio & desequilibrio & desequilíbrio & desequilíbrio & desequilíbrio \\
\hline despretensioso & despretencioso & despretensioso & despretensioso & despretensioso \\
\hline dignatários & dignitários & dignatários & digitarias & dignatários \\
\hline dispender & despender & dispender & - & despendes \\
\hline dispêndio & dispendio & dispundio & dispundio & dispendioso \\
\hline ecrã & ecran & - & écran & écran \\
\hline emirados & emiratos & estratos & méritos & emirados \\
\hline esotérico & isotérico & - & - & esotérico \\
\hline esquisito & esquesito & esquisito & esquisito & esquisito \\
\hline estratego & estratega & estratego & 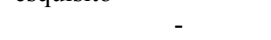 & estratego \\
\hline feminino & femenino & feminino & feminino & feminino \\
\hline feminismo & femininismo & - & feminismo & feminismo \\
\hline fôr & for & - & - & forcar \\
\hline gineceu & geneceu & gineceu & gineceu & $\overline{\text { gineceu }}$ \\
\hline gorjeta & gorgeta & gorjeta & gorjeta & gorjeta \\
\hline granjear & grangear & granjear & granjear & granjear \\
\hline guisar & guizar & guisar & gizar & guinar \\
\hline halariedade & hilaridade & hilariedade & - & polaridade \\
\hline hectare & hectar & hectare & - & hectare \\
\hline hiroshima & hiroxima & aproxima & próxima & hiroshima \\
\hline ilacção & elação & ilação & ilação & delação \\
\hline indispensável & indespensável & indispensável & indispensável & indispensável \\
\hline inflacção & inflação & - & - & inalação \\
\hline interveio & interviu & intervir & $\underline{\text { Inter viu }}$ & intervim \\
\hline intervindo & intervido & intervindo & - & intervindo \\
\hline invocar & evocar & invocar & - & evocai \\
\hline
\end{tabular}




\begin{tabular}{|c|c|c|c|c|}
\hline Correct Form & Spelling Error & TST & Aspell & MultiSpell \\
\hline ípsilon & ipslon & ípsilon & ípsilon & ípsilon \\
\hline irisar & irizar & irisar & razar & irisar \\
\hline irupção & irrupção & - & $\overline{-}$ & irupção \\
\hline jeropiga & geropiga & jeropiga & Georgia & jeropiga \\
\hline juiz & juíz & - & juiz & Juiz \\
\hline lampião & lampeão & lampião & sarjeta & campeão \\
\hline lêem & lêm & lês & lema & lêem \\
\hline linguista & linguísta & - & linguista & linguista \\
\hline lisonjear & lisongear & lisonjear & lisonjear & lisonjear \\
\hline logótipo & logotipo & logo tipo & logo tipo & logótipo \\
\hline maciço & massiço & mássico & mássico & massudo \\
\hline majestade & magestade & majestade & majestade & $\overline{\text { majestade }}$ \\
\hline manjerico & mangerico & manjerico & manjerico & manjerico \\
\hline manjerona & mangerona & tangerina & tangerina & manjerona \\
\hline meteorologia & metereologia & meteorologia & meteorologia & meteorologia \\
\hline miscigenação & miscegenação & miscigenação & miscigenação & miscigenação \\
\hline nonagésimo & nonagessimo & nonagésimo & nonagésimo & nonagésimo \\
\hline oceânia & oceania & oceânia & Oceania & oceânia \\
\hline oficina & ofecina & oficina & $\overline{\text { oficina }}$ & oficina \\
\hline opróbrio & opróbio & aeróbio & próbio & opróbrio \\
\hline organograma & organigrama & organograma & - & organograma \\
\hline paralisar & paralizar & paralisar & paralisar & paralisar \\
\hline perserverança & preseverança & perserverança & perserverança & perseverance \\
\hline persuasão & persuação & persuasão & persuasão & persuasão \\
\hline pirinéus & pirenéus & - & pirinéus & pirinéus \\
\hline pretensioso & pretencioso & pretensioso & pretensioso & pretensioso \\
\hline privilégio & previlégio & privilégios & privilégios & privilegios \\
\hline quadricromia & quadricomia & quadricromia & quadriculai & quadricromia \\
\hline quadruplicado & quadriplicado & quadruplicado & quadruplicado & quadruplicado \\
\hline quasímodo & quasimodo & - & quisido & quasímodo \\
\hline quilo & kilo & quilo & Nilo & dilo \\
\hline quilograma & kilograma & holograma & holograma & holograma \\
\hline quilómetro & kilómetro & $\overline{\text { milímetro }}$ & $\overline{\text { milímetro }}$ & $\overline{\text { quilómetro }}$ \\
\hline quis & quiz & quis & qui & juiz \\
\hline rainha & raínha & rainha & rainha & rainha \\
\hline raiz & raíz & - & raiz & raiz \\
\hline raul & raúl & raul & Raul & raul \\
\hline rectaguarda & retaguarda & rectaguarda & - & rectaguarda \\
\hline rédea & rédia & rédea & $\underline{\text { radia }}$ & radia \\
\hline regurgitar & regurjitar & regurgitar & regurgitar & regurgitar \\
\hline rejeitar & regeitar & rejeitar & regatar & receitar \\
\hline requeiro & requero & requere & $\overline{\text { requeiro }}$ & $\overline{\text { requer }}$ \\
\hline réstia & réstea & réstia & resta & réstia \\
\hline rubrica & rúbrica & rúbreca & rubrica & rubrica \\
\hline saem & saiem & saiam & saem & caiem \\
\hline saloiice & saloice & $\overline{\text { baloice }}$ & saloiice & saloiice \\
\hline sarjeta & sargeta & $\overline{\text { sarjeta }}$ & sarjeta & Sarjeta \\
\hline semear & semiar & semear & semear & Semear \\
\hline suíça & suiça & suíça & suíça & Suíça \\
\hline supor & supôr & - & supor & Supôs \\
\hline trânsfuga & transfuga & transfira & transfira & trânsfuga \\
\hline transpôr & transpor & - & - & transportar \\
\hline urano & úrano & - & - & grano \\
\hline ventoinha & ventoínha & ventoinha & ventoinha & ventoinha \\
\hline verosímil & verosímel & - & - & verosímil \\
\hline vigilante & vegilante & vigilante & vigilante & vigilante \\
\hline vôo & voo & - & - & ovo \\
\hline vultuoso & vultoso & vultuoso & - & vultosos \\
\hline xadrez & xadrês & xadrez & ladres & $\overline{\text { xadrez }}$ \\
\hline xamã & chamã & chama & chama & chamá \\
\hline xelindró & xilindró & cilindro & cilindro & xelindró \\
\hline zângão & zangão & zangai & - & mangão \\
\hline zepelin & zeppelin & zepelim & zeplim & zepelin \\
\hline zoo & zoô & $\overline{\text { zoo }}$ & $\overline{c 00}$ & zoo \\
\hline
\end{tabular}

\section{REFERENCES}

[1] K. Kukich, "Techniques for automatically correcting words in text," ACM Computing Surveys, 24(4), 377-439, 1992.

[2] F. J. Damerau, "A technique for computer detection and correction of spelling errors," Communications of ACM, 7(3):171-176.7, 1964.
[3] W. Peters, "Lexical Resources," NLP group, Dept. of Comp. Sc., Uni. of Sheffield, 2001.

[4] R. A. Wagner and M. J. Fisher, "The string to string correction problem," Journal of Assoc. Comp. Mach., 21(1):168-173, 1974.

[5] A. Stanier, "How accurate is Soundex matching?" Comp. in Genealogy, vol. 3:7, 1990.

[6] C. Fellbaum, "WordNet, an electronical lexical database," Cambridge, MIT Press, 1998. 
[7] E. Pianta, L. Bentivogli, and C. Girardi, "MultiWordNet: developing an aligned multilingual database," in Proc. of 1st Int. Conf. on Global WordNet, 2002.

[8] C. E. Shannon, "Prediction and entropy of printed English," Bell Sys. Tec. J. (30):50-64, 1951.

[9] U. Pfeifer, "Retrieval Effectiveness of Proper Name Search Methods," Information Processing and Management, 32(6):667-679, 1996.

[10] E. J. Yannakoudakis and D. Fawthrop, "An intelligent spelling error corrector," Information Processing and Management, 19:1, 101-108, 1983.

[11] T. N. Turba, "Length-segmented lists," Comm. of the ACM, 25:8, pp $522-526,1982$.

[12] Wikipedia, list of Common Misspelling Word List, http://en.wikipedia.org/wiki/Wikipedia: List_of_common_misspellings, 05.10 .2006$.

[13] B. Martins, M. J. Silva, "Spelling Correction for Search Engine Queries," in EsTAL - España for Natural Language Processing, Alicante, Spain, 2004.

[14] K. Church and W. A. Gale, "Probability scoring for spelling correction," Statistics and Computing, Vol. 1, No. 1, pp. 93-103, 1991.

[15] V. J. Hodge and J. Austin, "A comparison of standard spell checking algorithms and novel binary neural approach," IEEE Trans. Know. Dat. Eng., Vol. 15:5, pp. 1073-1081, 2003.

[16] J. J. Pollock and A. Zamora, "Collection and characterization of spelling errors in scientific and scholarly text," Journal Amer. Soc. Inf. Sci., Vol. 34, No. 1, pp. 51-58, 1983.

[17] - "Automatic spelling correction in scientific and scholarly text," Comm. ACM, Vol. 27, No. 4, pp. 358-368, 1984.

[18] E. Brill and R. C. Moore, "An improved error model for noisy channel spelling correction," in Proc. 38th Annual Meet. of the Assoc. for Comp. Ling., Hong Kong, 2000, pp. 286-293.

[19] K. Toutanova and R. C. Moore, "Pronunciation modeling for improved spelling correction," in Proc. 40th Annual Meeting of the Assoc. for Comp. Ling., Hong Kong, 2002, pp. 144-151.

[20] Jin-ming Zhan, Xiaolong Mou, Shuqing Li, Ditang Fang, "A Language Model in a Large-Vocabulary Speech Recognition System," in Proc. of Int. Conf. ICSLP98, Sydney, Australia, 1998.

[21] S. Deorowicz and M. G. Ciura, "Correcting Spelling Errors by Modelling Their Causes," Int. Journal of Applied Mathematics and Computer Science, 15(2):275-285, 2005.

[22] B. Khaltar, A. Fujii, and T. Ishikawa, "Extracting loanwords from Mongolian corpora and producing a Japanese-Mongolian bilingual dictionary," in Proceedings of the 21st International Conference on Computational Linguistics and the 44th Annual Meeting of the ACL, Sydney, Australia: ACL. Pages: 657 - 664, 2006.

[23] E. W. De Luca and A. Nürnberger, "Using Clustering Methods to Improve Ontology-Based Query Term Disambiguation," International Journal of Intelligent Systems, 21:693-709, 2006.

[24] E. W. De Luca and A. Nürnberger, "Rebuilding Lexical Resources for Information Retrieval using Sense Folder Detection and Merging Methods,"in: Proc. of the 5th Int. Conf. on Language Resources and Evaluation (LREC 2006), 2006.

[25] E. W. De Luca, "Semantic Support in Multilingual Text Retrieval," Shaker Verlag, Aachen, Germany, 2008. 